\title{
Magnesium Borate Synthesis by Microwave Energy: A New Method
}

\author{
Azmi Seyhun Kipcak, Emek Moroydor Derun, and Sabriye Piskin \\ Chemical Engineering Department, Faculty of Chemical and Metallurgical Engineering, Yildiz Technical University, \\ 34210 Istanbul, Turkey
}

Correspondence should be addressed to Emek Moroydor Derun; moroydor@gmail.com

Received 28 January 2013; Accepted 27 March 2013

Academic Editor: A. M. S. Silva

Copyright (C) 2013 Azmi Seyhun Kipcak et al. This is an open access article distributed under the Creative Commons Attribution License, which permits unrestricted use, distribution, and reproduction in any medium, provided the original work is properly cited.

\begin{abstract}
Magnesium borates are one of the major groups of boron minerals that have important properties such as high heat and corrosion resistances and high coefficients of elasticity. In this study, magnesium borate minerals are synthesized using boric acid and magnesium oxide with a new method of microwave, and the synthesized minerals are characterized by various analysis techniques. The results show that pure, "magnesium borate hydrate" minerals are obtained at the end of various steps. The characterization of the products is determined with the techniques of X-Ray Diffraction (XRD), Fourier Transform Infrared Spectroscopy (FTIR), Raman Spectroscopy, and Scanning Electron Microscopy (SEM). Additionally, overall "magnesium borate hydrate" yields are calculated and found about $67 \%$ at $270 \mathrm{~W}, 8$ minutes and $360 \mathrm{~W}, 3$ minutes of reaction times, respectively.
\end{abstract}

\section{Introduction}

The boron reserves of the world are majorly located in Turkey, Russia, and USA. The total amount of these reserves is known as 1.2 billion tons, $72.2 \%$ of which is present in Turkey, $8.5 \%$ in Russia, and $6.8 \%$ in USA. When compared with other boron minerals, magnesium borates are less refinely produced and this production takes place at the region of Liao-Dong peninsula, adjacent to North Korea part of China. The production method is mainly mining from the subterranean or production from the sea water with double salt transformation [1].

Magnesium borates can be used as an alternative magnesium and/or boron source, other refined borates, or metal borates. Their application areas involve ceramic industry, detergent industry, fire-retardants, lens solutions, superconducting materials production, hydrocarbon catalysts, additive, or oils for friction reduction agents, due to their superior properties such as high elastic coefficient, resistance to dust, and high resistance to heat. In addition to the aforementioned application areas, magnesium borates can also be used as a neutron and gamma radiation shield material, owing to the high percentage of boron elements and crystal waters present inside [1-3].
There are lots of magnesium borate minerals synthesized from different methods or acquired naturally with different compositions, which can be used for various applications. Hydroboracite $\left(\mathrm{CaMgB}_{6} \mathrm{O}_{11} \cdot 6 \mathrm{H}_{2} \mathrm{O}\right)$ and szaibelyite $\left(\mathrm{Mg}_{2} \mathrm{~B}_{2} \mathrm{O}_{5} \cdot \mathrm{H}_{2} \mathrm{O}\right)$ are the natural types of commercial magnesium borate minerals. Besides them, the closed formulas of the synthesized magnesium borate minerals can be given as $\mathrm{MgO} \cdot\left(\mathrm{B}_{2} \mathrm{O}_{3}\right) \cdot n \mathrm{H}_{2} \mathrm{O}, \mathrm{MgO} \cdot 3\left(\mathrm{~B}_{2} \mathrm{O}_{3}\right) \cdot n \mathrm{H}_{2} \mathrm{O}$, $2 \mathrm{MgO} \cdot\left(\mathrm{B}_{2} \mathrm{O}_{3}\right) \cdot n \mathrm{H}_{2} \mathrm{O}$, and $2 \mathrm{MgO} \cdot\left(3 \mathrm{~B}_{2} \mathrm{O}_{3}\right) \cdot n \mathrm{H}_{2} \mathrm{O}$. Since szaibelyite, boracite, and chloropinnoite, the most known type of magnesium borates, are found in China, the synthesis studies are done mostly in this region [4].

In the microwave method, which can be included in the solid-state method, the boron and magnesium sources are mixed homogeneously at their solid form, and then react with each other at a microwave furnace in an air atmosphere. Using the solid-state method many types of dehydrated magnesium borates are synthesized in literature. For instance, Došler et al. synthesized a major phase of $\mathrm{Mg}_{3} \mathrm{~B}_{2} \mathrm{O}_{6}$ at $1300^{\circ} \mathrm{C}$ and $\mathrm{Mg}_{2} \mathrm{~B}_{2} \mathrm{O}_{5}$ at $1000^{\circ} \mathrm{C}$, using the starting materials of boron oxide and magnesium oxide [5]. Guler et al. synthesized pure $\mathrm{Mg}_{2} \mathrm{~B}_{2} \mathrm{O}_{5}$ at $900^{\circ} \mathrm{C}$ using boric acid and magnesium oxide and stated that the reaction started at a temperature of $600^{\circ} \mathrm{C}$ [6]. Qasrawi et al. investigated 
the thermal characterization of $\mathrm{Mg}_{2} \mathrm{~B}_{2} \mathrm{O}_{5}$ crystals after three hours of calcination time and $1250^{\circ} \mathrm{C}$ calcination temperature and stated a $42 \%$ weight loss [7]. Elssfah et al. used a same way with Došler et al., but they used $\mathrm{Mg}(\mathrm{OH})_{2}$ as the magnesium source. They synthesized a magnesium borate crystal with a radius of 70-120 nm [8]. $\mathrm{Li}$ et al. produced $\mathrm{Mg}_{2} \mathrm{~B}_{2} \mathrm{O}_{5}$ from the materials of $\mathrm{MgCl}_{2} \cdot 6 \mathrm{H}_{2} \mathrm{O}$ and $\mathrm{NaBH}_{4}$ at $800^{\circ} \mathrm{C}$ and 2 hours [9]. Erdogan used $\mathrm{Mg}\left(\mathrm{NO}_{3}\right)_{2}$ and boric acid [10]; Ay used $\mathrm{Mg}\left(\mathrm{NO}_{3}\right)_{2} \cdot 6 \mathrm{H}_{2} \mathrm{O}$ and boron oxide for the synthesizing magnesium borates [11]. Zhang et al. synthesized 100-300 nm particle sized $\mathrm{Mg}_{3} \mathrm{~B}_{2} \mathrm{O}_{6}$ with a quartz furnace at $1100^{\circ} \mathrm{C}$ for 90 minutes of reaction time [12]. There are several other studies including magnesium borate synthesis for the method of solid-state [13-16]. Among all of these studies only the two of them contain the microwave method. Guler et al. used magnesium oxide and boric acid as a starting materials and used a synthesis procedure at $700 \mathrm{~W}$ power and 10 minutes of reaction time, but the synthesized products were found as amorphous [6]. Ay used a same procedure with Guler et al.; in his study he used $\mathrm{Mg}\left(\mathrm{NO}_{3}\right)_{2} \cdot 6 \mathrm{H}_{2} \mathrm{O}$ as magnesium source and the final products are found to be again amorphous [11].

As it is seen from the literature, various types of starting materials for magnesium borates are studied with the solidstate method. Only two studies included the microwave energy; however, their results are not promising. In this study, the production of crystalline magnesium borates is aimed for the method of microwave energy. Some preliminary experiments are done [17] and it is seen that the crystalline formation of magnesium borates is possible with this method.

\section{Materials and Methods}

2.1. Preparation and Identification of the Reactants. The boron source of boric acid $\left(\mathrm{H}_{3} \mathrm{BO}_{3}\right)$ is retrieved from EtiBank Bandirma Boron and Acid Factory. Boric acid is first crushed then grinded with Retsch brand agate mortar. Grinded minerals are sieved with Fritsch brand sieving equipment with a $75 \mu \mathrm{m}$ sieve. The magnesium source of magnesium oxide is bought from Merck chemicals (99.9\% purity) and used without pretreatment. In order to identify the boric acid and magnesium oxide compounds, Philips Panalytical, X-Ray Diffraction (XRD) equipment is used with $\mathrm{Cu}-\mathrm{K} \alpha$ tube, with the parameters of $45 \mathrm{kV}$ and $40 \mathrm{~mA}$.

Perkin Elmer brand Fourier Transform Infrared Spectroscopy (FT-IR) with Attenuation Total Reflection (ATR) apparatus is used to the products with scan number of 4 , resolution of $4 \mathrm{~cm}^{-1}$, and scan range of $1800 \mathrm{~cm}^{-1}-650 \mathrm{~cm}^{-1}$. In order to strengthen the results, Perkin Elmer brand Raman Station 400F, Raman Spectroscopy is used with scan number of 4 , scan time of 4 seconds, and scan range of $1400 \mathrm{~cm}^{-1}$ $250 \mathrm{~cm}^{-1}$.

\subsection{Microwave Synthesis of Magnesium Borate Hydrates.} These syntheses are made through 4 steps. In the first step, the magnesium oxide and boric acid mole ratio is selected as $1: 1$. Then the mixtures are mixed homogeneously and pelleted with Manfredi brand OL57 model press equipment at a pressure of 100 bars. In this step, the microwave power is selected as $270 \mathrm{~W}$ and $360 \mathrm{~W}$. The reaction time is selected as 2, 5, and 8 minutes. The syntheses are made with using alumina coated ceramic crucibles. From the results of the first step experiments, the second step is planned. In second step, $270 \mathrm{~W}$ power and 8 minutes of reaction time are set as constant and the mole ratio of magnesium to boron was scanned from $2: 1$ to $1: 10$. In the third step the best mole ratio from the second step is kept constant, and the power and reaction temperatures are varied. At $270 \mathrm{~W}$ the reaction time is selected between 6 and 12 minutes, whereas at $360 \mathrm{~W}$, the reaction time is selected between 1 and 4 minutes and at $600 \mathrm{~W}$, the reaction time is selected between 0.5 and 2 minutes. At the last step, the best results from the $270 \mathrm{~W}$, $360 \mathrm{~W}$, and $600 \mathrm{~W}$ power are selected and washed with pure ethanol solution (96\%) in order to eliminate the excess boric acid from the products.

2.3. Reaction Yields. In the case of reaction yield based on molar flow rates, the overall yield, $Y_{D}$, is defined as the ratio of moles of product formed at the end of the reaction, $N_{D}$, to the number of moles of the key reactant, $A$, that have been consumed. $N_{A 0}$ and $N_{A}$ are the initial and final moles of consumed reactant, respectively. For a batch system [18]:

$$
Y_{D}=\frac{N_{D}}{N_{A 0}-N_{A}} .
$$

Using magnesium oxide as the key reactant, five parallel experiments were conducted.

2.4. Characterization of the Synthesized Products. To identify the synthesized magnesium borate minerals, X-Ray Diffraction (XRD), Fourier Transform Infrared Spectroscopy (FTIR), and Raman Spectroscopy techniques are used with the parameter sets previously mentioned in Section 2.1.

To evaluate the commercial values of the boron minerals, their boron oxide $\left(\mathrm{B}_{2} \mathrm{O}_{3}\right)$ contents must be known. In order to achieve this, 1 gram of produced magnesium borates, obtained from step 4 , is dissolved in $3 \mathrm{~mL}, 37 \% \mathrm{HCl}$ solution and diluted to $100 \mathrm{~mL}$ with pure water $(18.3 \mathrm{~m} \Omega \cdot \mathrm{cm})$ obtained from Human Power $\mathrm{I}^{+}$Water Purification System. Pure boric acid is also used for the reference material at the same conditions. Then $\mathrm{NaOH}$ solution with known molar value is used with Metrohm brand 794 Basic Titrano model titration equipment, for the titrations. After the titrations, the boron oxide contents of step 4 synthesized minerals are calculated.

Lastly to identify the morphology and particle size of the synthesized step 4 minerals, CamScan Apollo 300 fieldemission Scanning Electron Microscopy (SEM-EDX) is used at $20 \mathrm{kV}$. Back Scattering Electron (BEI) detector is used and the magnifications were set between 5000 and 10000x.

\section{Results and Discussion}

3.1. X-Ray Diffraction Results. The reactants used in the experiments are analyzed and found to be "Periclase $[\mathrm{MgO}]$ " and "Sassolite $\left[\mathrm{H}_{3} \mathrm{BO}_{3}\right]$ " with reference codes of 01-077-2179 and 01-073-2158, respectively. XRD results of step 1 and step 2 products are shown in Table 1 . Step 3 and step 4 products are 
TABLE 1: XRD scores of step 1 and 2 synthesized products.

\begin{tabular}{|c|c|c|c|c|c|c|}
\hline \multirow[t]{2}{*}{$\begin{array}{l}\text { Step } \\
\text { no. }\end{array}$} & \multirow[t]{2}{*}{$\begin{array}{l}\text { Power } \\
(\mathrm{W})\end{array}$} & \multirow[t]{2}{*}{$\begin{array}{l}\text { Time } \\
(\text { mins })\end{array}$} & \multirow[t]{2}{*}{$\mathrm{M}: \mathrm{B}$} & \multicolumn{3}{|c|}{$\begin{array}{l}\text { XRD scores of the synthesized } \\
\text { products }\end{array}$} \\
\hline & & & & $\dagger$ & $\#$ & $\wedge$ \\
\hline \multirow{6}{*}{1} & \multirow{3}{*}{270} & 2 & $1: 1$ & 74 & 41 & - \\
\hline & & 5 & $1: 1$ & 69 & 35 & 32 \\
\hline & & 8 & $1: 1$ & 69 & 37 & 38 \\
\hline & \multirow{3}{*}{360} & 2 & $1: 1$ & 68 & 40 & 30 \\
\hline & & 5 & $1: 1$ & 65 & 23 & 20 \\
\hline & & 8 & $1: 1$ & 81 & 15 & - \\
\hline \multirow{7}{*}{2} & \multirow{7}{*}{270} & \multirow{7}{*}{8} & $2: 1$ & 74 & 38 & - \\
\hline & & & $1: 1$ & 65 & 41 & 35 \\
\hline & & & $1: 2$ & 54 & 43 & 42 \\
\hline & & & $1: 4$ & - & 61 & 52 \\
\hline & & & $1: 6$ & - & 55 & 47 \\
\hline & & & $1: 8$ & - & 61 & 51 \\
\hline & & & $1: 10$ & - & 32 & 49 \\
\hline
\end{tabular}

${ }^{*} \mathrm{M}: \mathrm{MgO}, \mathrm{H}: \mathrm{H}_{3} \mathrm{BO}_{3}$.

${ }^{\dagger}$ Periclase, pdf \# = 01-077-2179, $\mathrm{MgO}$.

${ }^{\ddagger}$ Sassolite, pdf \# = 01-073-2158, $\mathrm{H}_{3} \mathrm{BO}_{3}$.

${ }^{\wedge}$ Magnesium Borate Hydrate, pdf \# 01-076-0539, $\mathrm{MgO}\left(\mathrm{B}_{2} \mathrm{O}_{3}\right)_{3} \cdot 6\left(\mathrm{H}_{2} \mathrm{O}\right)$.

TABLE 2: XRD scores of step 3 and 4 synthesized products.

\begin{tabular}{|c|c|c|c|c|c|c|}
\hline \multirow[t]{2}{*}{$\begin{array}{l}\text { Step } \\
\text { no. }\end{array}$} & \multirow[t]{2}{*}{$\begin{array}{c}\text { Power } \\
(\mathrm{W})\end{array}$} & \multirow[t]{2}{*}{$\begin{array}{l}\text { Time } \\
\text { (mins) }\end{array}$} & \multirow[t]{2}{*}{$\mathrm{M}: \mathrm{B}$} & \multicolumn{3}{|c|}{$\begin{array}{l}\text { XRD scores of the synthesized } \\
\text { products }\end{array}$} \\
\hline & & & & $\dagger$ & $\neq$ & $\wedge$ \\
\hline \multirow{12}{*}{3} & \multirow{4}{*}{270} & 6 & \multirow{4}{*}{$1: 4$} & - & 56 & 39 \\
\hline & & 8 & & - & 61 & 52 \\
\hline & & 10 & & - & 53 & 45 \\
\hline & & 12 & & - & 43 & 30 \\
\hline & \multirow{4}{*}{360} & 1 & \multirow{4}{*}{$1: 4$} & - & 54 & 7 \\
\hline & & 2 & & - & 62 & 46 \\
\hline & & 3 & & - & 48 & 47 \\
\hline & & 4 & & - & 51 & 35 \\
\hline & \multirow{4}{*}{600} & 0.5 & \multirow{4}{*}{$1: 4$} & - & 66 & 10 \\
\hline & & 1 & & - & 49 & 44 \\
\hline & & 1.5 & & - & 50 & 43 \\
\hline & & 2 & & - & 25 & 16 \\
\hline \multirow{3}{*}{4} & 270 & 8 & $1: 4$ & - & - & 69 \\
\hline & 360 & 3 & $1: 4$ & - & - & 61 \\
\hline & 600 & 1 & $1: 4$ & - & - & 65 \\
\hline
\end{tabular}

${ }^{*} \mathrm{M}: \mathrm{MgO}, \mathrm{H}: \mathrm{H}_{3} \mathrm{BO}_{3}$.

${ }^{\dagger}$ Periclase, pdf \# = 01-077-2179, $\mathrm{MgO}$.

${ }^{\ddagger}$ Sassolite, pdf \# = 01-073-2158, $\mathrm{H}_{3} \mathrm{BO}_{3}$.

${ }^{\wedge}$ Magnesium Borate Hydrate, pdf \# 01-076-0539, $\mathrm{MgO}\left(\mathrm{B}_{2} \mathrm{O}_{3}\right)_{3} \cdot 6\left(\mathrm{H}_{2} \mathrm{O}\right)$.

shown in Table 2. XRD patterns of step 4 minerals are given in Figure 1.

From the first step results it is seen that the magnesium borate formation started after the reaction time of 2 minutes at $270 \mathrm{~W}$ and turned to the amorphous phase after 8 minutes of reaction time, at $360 \mathrm{~W}$ power. The crystal scores are increased for the reaction time of 5 to 8 minutes at $270 \mathrm{~W}$ power and decreased for the reaction time of 2 to 5 minutes at $360 \mathrm{~W}$ power. The maximum formation is seen on $270 \mathrm{~W}$,

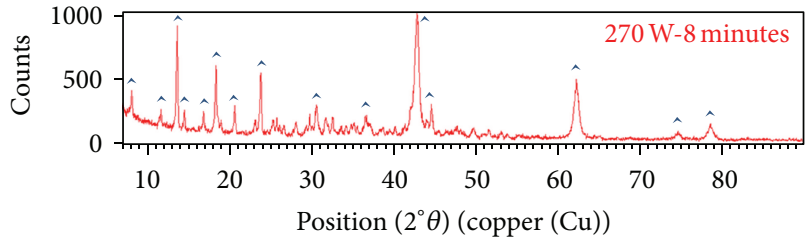

(a)

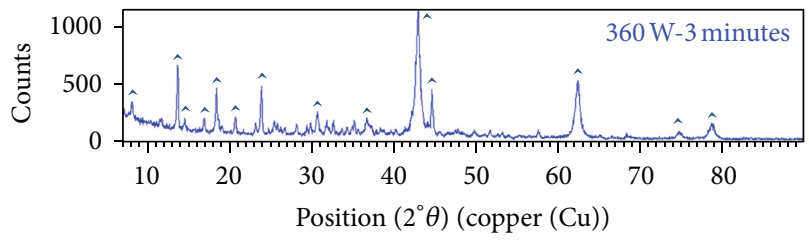

(b)

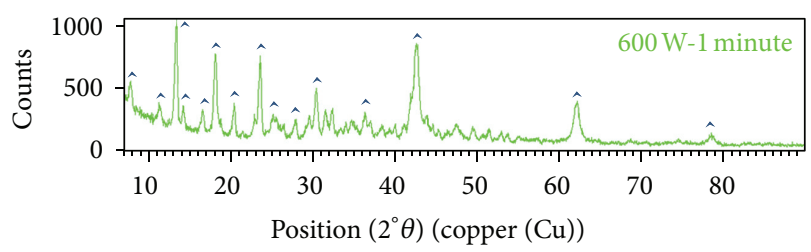

(c)

FIGURE 1: XRD patterns of the synthesized "magnesium borate hydrate" minerals after step 4.

8 minutes of reaction time. Then at the second step, $270 \mathrm{~W}$ and 8 minutes of reaction time are set to constant and mole ratios are varied. From the results obtained it is seen that the periclase peaks are disappeared after the mole ratio of $1: 2$. Since at the ratios of $2: 1$ to $1: 2$ excess magnesium oxide are used, periclase peaks are predictable. But between the ratios of $1: 4$ and $1: 10$ excess boric acid is used. At the ratios of $1: 4$ and $1: 8$ the crystal scores of "magnesium borate hydrate" are 52 and 51, respectively, and these ratios crystal scores are higher than the other scores. So at step 3 the ratio of $1: 4$ is selected as constant and power and reaction times are varied.

At step 3, three different microwave powers are used which are 270,360 , and $600 \mathrm{~W}$. For $270 \mathrm{~W}$ the reaction times are selected 6 to 12 with a step increase of 2 minutes. For $360 \mathrm{~W}$ the reaction times are set as 1 to 4 with a step increase of 1 minute, and at $600 \mathrm{~W}$ reaction times are set between 0.5 and 2 minutes, with a step increase of 0.5 minutes. The highest crystal scores of "magnesium borate hydrate" are obtained as 52,47 , and 44 with 270,360 , and $600 \mathrm{~W}$ power, respectively. But at all these experiments the sassolite peaks are seen, because of the excess boric acid amounts. In order to get rid of these sassolite peaks and purify the "magnesium borate hydrate" minerals, the minerals are washed with $96 \%$ ethanol in step 4. Then it is seen that the crystal scores of "magnesium borate hydrate" minerals are obtained as 69 at $270 \mathrm{~W}, 61$ at $360 \mathrm{~W}$, and 65 at $600 \mathrm{~W}$.

3.2. FT-IR, Raman, $\mathrm{B}_{2} \mathrm{O}_{3}$, SEM, and Overall Yield Results. FT-IR and Raman spectroscopic data for synthesized "magnesium borate hydrate" minerals at step 4 are presented in Figures 2 and 3, respectively. $\mathrm{B}_{2} \mathrm{O}_{3}$ results and SEM 
TABLE 3: $\mathrm{B}_{2} \mathrm{O}_{3}$ results of step 4 synthesized "magnesium borate hydrate" minerals.

\begin{tabular}{lccc}
\hline Power $(\mathrm{W})$ & Time (mins) & $\mathrm{Mg}: \mathrm{B}$ ratio & $\mathrm{B}_{2} \mathrm{O}_{3}(\%)$ \\
\hline 270 & 8 & $1: 4$ & $53.23 \pm 0.87$ \\
360 & 3 & $1: 4$ & $55.17 \pm 0.62$ \\
600 & 1 & $1: 4$ & $51.73 \pm 0.75$ \\
\hline
\end{tabular}

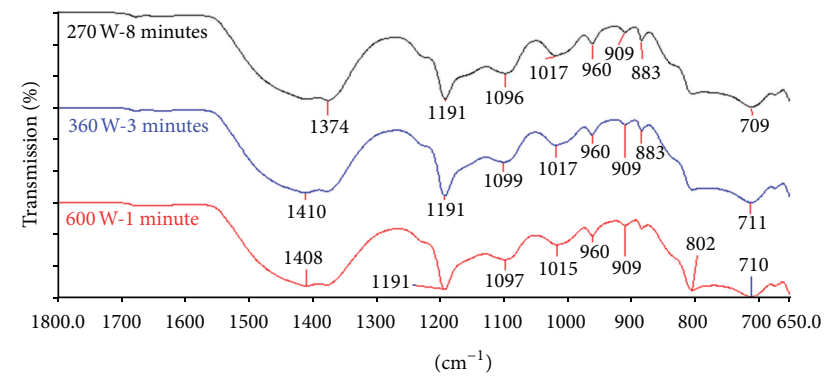

FIGURE 2: FT-IR spectrums of the synthesized "magnesium borate hydrate" minerals after step 4.

morphology photos are also given in Table 3 and Figure 4 through Figure 6, respectively.

According to the FT-IR spectrums, the peak values of 1410 and $1408 \mathrm{~cm}^{-1}$ represent the asymmetric stretching of the three-coordinate boron $\left(\mathrm{B}_{(3)}-\mathrm{O}\right)$. The peak of $1374 \mathrm{~cm}^{-1}$, which is shown in $270 \mathrm{~W}, 8$ minutes reaction time, represents the in-plane $\mathrm{OH}^{-1}$ bending. Asymmetric and symmetric stretching of four-coordinate boron $\left(\mathrm{B}_{(4)}-\mathrm{O}\right)$ occurred at the peak values between 1191 and $960 \mathrm{~cm}^{-1}$ and $909-883 \mathrm{~cm}^{-1}$, respectively. Out-of plane $\mathrm{OH}^{-1}$ bending is seen at the peak value of $802 \mathrm{~cm}^{-1}$ at the $600 \mathrm{~W}, 1$ minute reaction time only. Lastly, bending of $\mathrm{B}_{(3)}-\mathrm{O}$ occurred at the peak values of 711 and $709 \mathrm{~cm}^{-1}$.

From the Raman results, it is seen that the $600 \mathrm{~W}, 1$ minute of reaction time spectrum cannot be obtained due to the fluorescence effect of this mineral. Asymmetric stretching of $\mathrm{B}_{(3)}{ }^{-}$ $\mathrm{O}$ is seen at the peak value of $1249 \mathrm{~cm}^{-1}$ at $360 \mathrm{~W}, 3$ minutes of reaction time. Symmetric stretching of $\mathrm{B}_{(3)}-\mathrm{O}$ is seen at the peaks of 962 and $963 \mathrm{~cm}^{-1}$. Symmetric stretching of $\mathrm{B}_{(4)}-\mathrm{O}$ is only observed in the 240 minute synthesis, with the peak value of $881 \mathrm{~cm}^{-1}$. The anion of $\left[\mathrm{B}(\mathrm{OH})_{4}\right]^{-}$and stretching of $\mathrm{B}_{(3)}-\mathrm{O}$ peaks are observed at the peaks between 632 and $635 \mathrm{~cm}^{-1}$. At the last region the peaks between 427 and 318 are the anion of $\left[\mathrm{B}_{5} \mathrm{O}_{6}(\mathrm{OH})_{4}\right]^{-}$and stretching of $\mathrm{B}_{(4)}-\mathrm{O}$.

In accordance with the $\mathrm{B}_{2} \mathrm{O}_{3}$ results, it is seen that for all the synthesized products, $\mathrm{B}_{2} \mathrm{O}_{3}$ contents are nearly the same. The $\mathrm{B}_{2} \mathrm{O}_{3}$ content of magnesium borate hydrate minerals have been reported to be between $50-56 \%$. The maximum and minimum $\mathrm{B}_{2} \mathrm{O}_{3}$ content are found in $360 \mathrm{~W}$ (with the value of $55.17 \pm 0.62 \%$ ) and $600 \mathrm{~W}$ (with the value of $51.73 \pm$ $0.75 \%)$, respectively.

In Figure 4, minerals produced at a power of $270 \mathrm{~W}$ and 8 minutes of reaction time are shown with a magnification of 5000x and 10000x; here, "magnesium borate hydrate" minerals are crystallized in rectangular shapes and their particle sizes are found between 202.81 and $742.46 \mathrm{~nm}$. In

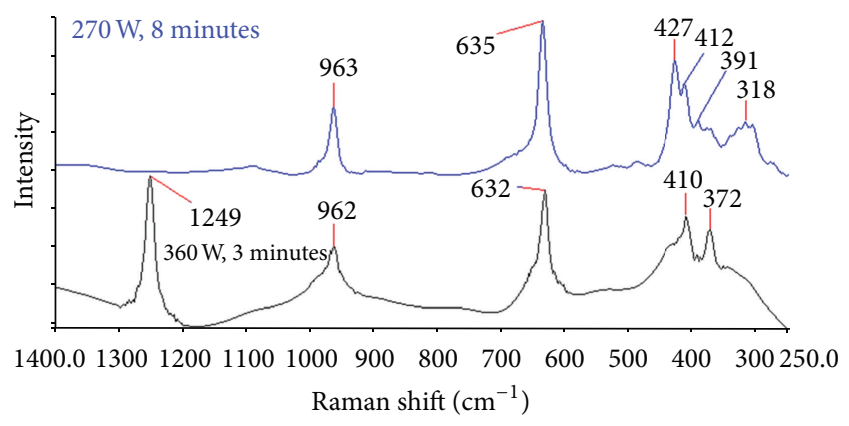

FIGURE 3: Raman spectrums of the synthesized "magnesium borate hydrate" minerals after step 4.

Figure 5, minerals produced at a power of $360 \mathrm{~W}$ and $3 \mathrm{~min}$ utes of reaction time are shown at a magnification of 5000x and 10000x; here, "magnesium borate hydrate" minerals are crystallized more likely in tubular rectangular shapes and their particle sizes are found between 151.17 and $730.29 \mathrm{~nm}$. In Figure 6, minerals produced at a power of $600 \mathrm{~W}$ and 1 minute of reaction time are shown at a magnification of $5000 \mathrm{x}$ and 10000x; here, "magnesium borate hydrate" minerals are agglomerated and some tubular rectangular shapes are formed. Their particle sizes are found between $293.99 \mathrm{~nm}$ and $1.19 \mu \mathrm{m}$.

Overall "magnesium borate hydrate" yields are obtained from the excess boric acid amounts that have been calculated from the washing step, to be $67.37 \pm 0.02 \%$ and $67.54 \pm 0.33 \%$ at $270 \mathrm{~W}, 8$ minutes and $360 \mathrm{~W}, 3$ minutes of reaction times, respectively. The standard deviation likely occurred due to the experimental errors during the filtration processes. At $600 \mathrm{~W}$, 1 minute of reaction time the overall yield is far more than the other reaction yields. So $600 \mathrm{~W}, 1$ minute reaction time is not a reasonable process.

\section{Conclusions}

In this study, the reactants of magnesium oxide and boric acid are used to produce magnesium borate hydrate by the microwave method at different microwave powers and reaction times. The synthesized minerals are characterized, and the results show that the properties of the synthesized "magnesium borate hydrate" minerals are in good agreement with those in the literature. The major result from this study, obtained from XRD analysis, is that the "magnesium borate hydrate" minerals can be easily synthesized at microwave power and reaction times of $270 \mathrm{~W}, 8$ minutes and $360 \mathrm{~W}, 3$ minutes. FT-IR and Raman results show that the synthesized minerals had the characteristic peaks of magnesium borates. Additionally, the synthesized minerals had $\mathrm{B}_{2} \mathrm{O}_{3}$ contents between the values of $51.73 \pm 0.75 \%$ and $55.17 \pm 0.62 \%$, which are comparable to the reported $\mathrm{B}_{2} \mathrm{O}_{3}$ content of 50$55 \%$ in magnesium borates. Additionally, it is seen from the SEM images that the particle sizes of the minerals are found as nanoscale at $270 \mathrm{~W}, 8$ minutes and $360 \mathrm{~W}, 3$ minutes. From the overall yield of the $270 \mathrm{~W}, 8$ minutes and $360 \mathrm{~W}$, 3 minutes reaction time synthesized "magnesium borate hydrate" minerals at about $67 \%$. For such low reaction times and microwave powers, this overall yield is a great value. 


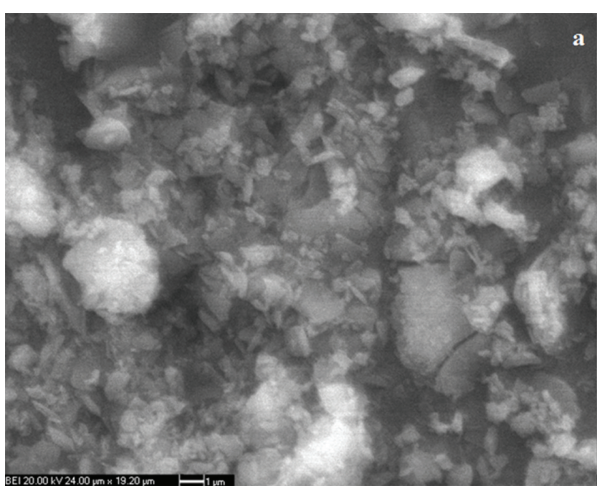

(a)

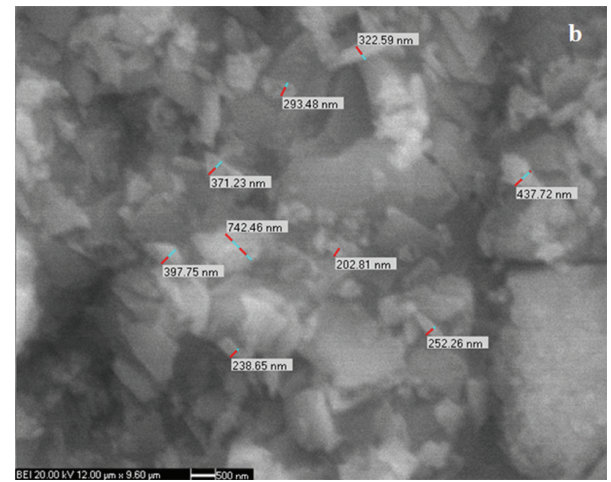

(b)

Figure 4: "Magnesium borate hydrate" minerals synthesized at $270 \mathrm{~W}$ and 8 minutes; (a) 5000x, (b) 10000x.

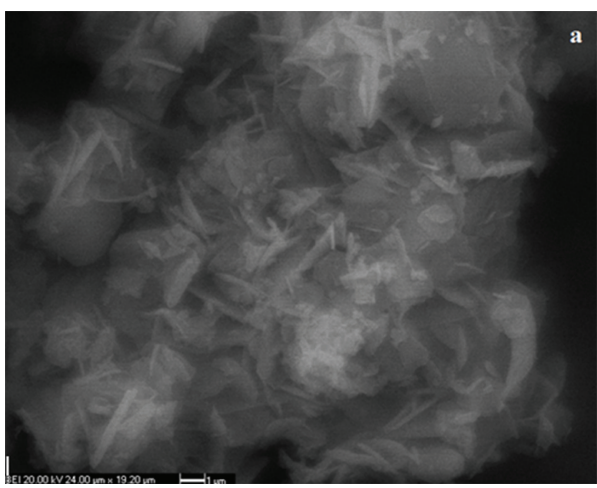

(a)

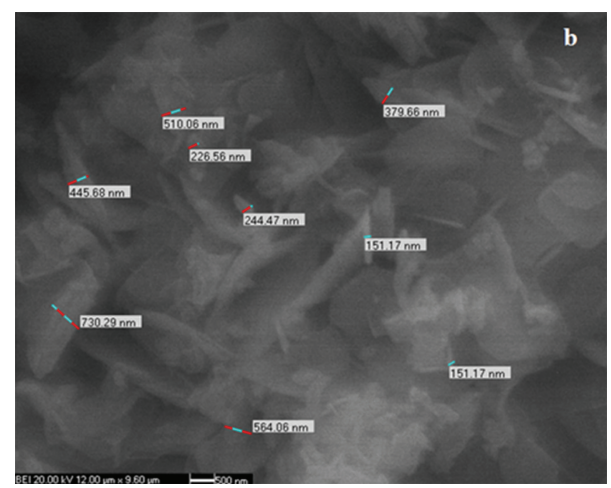

(b)

Figure 5: "Magnesium borate hydrate" minerals synthesized at $360 \mathrm{~W}$ and 3 minutes; (a) 5000x, (b) 10000x.

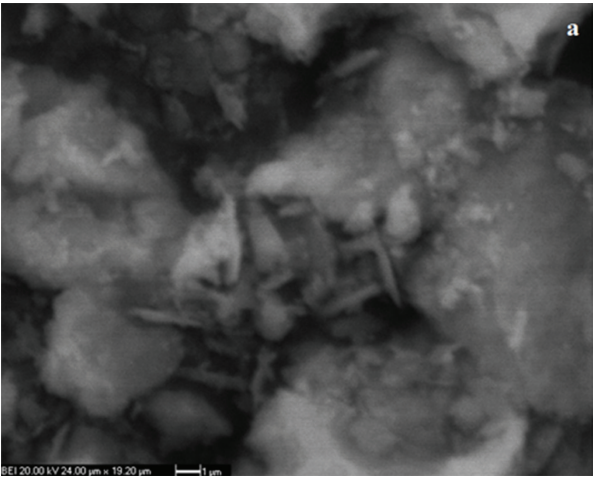

(a)

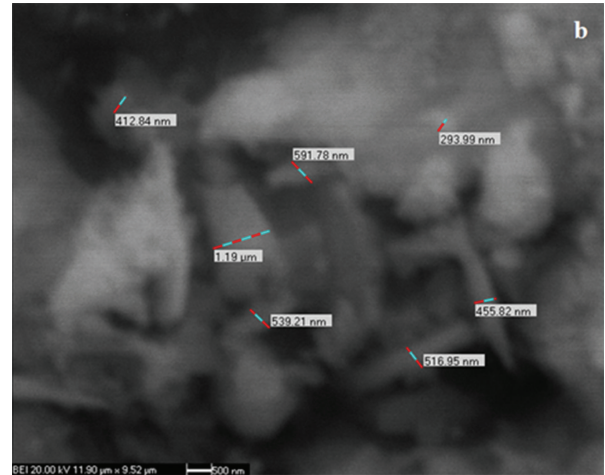

(b)

FIGURE 6: "Magnesium borate hydrate" minerals synthesized at $600 \mathrm{~W}$ and 1 minutes; (a) 5000x, (b) 10000x.

In this study $600 \mathrm{~W}, 1$ minute of reaction time is also studied and characterized but it had a lower overall yield, when compared with the other two minerals.

\section{References}

[1] "Boron Operations Group Report: Ninth development plan (2007-2013)," T. R. Prime Ministry SPO, Chemical Industry Private Expertise Commission, 2006.
[2] “Boron Sector Report," Etimine Works General Management, 2012.

[3] E. Sarihan, "Boron Sector Profile," Istanbul Chamber of Commerce, vol. 28, 2006 (Turkish).

[4] A. Obut and I. Girgin, "Magnezyum Boratlarin Sentezlenmesi ve Tanimlanmasi," in Proceedings of the 2nd International Boron Symposium, pp. 133-138, Eskisehir, Turkey, 2004.

[5] U. Došler, M. M. Kržmanc, and D. Suvorov, "The synthesis and microwave dielectric properties of $\mathrm{Mg}_{3} \mathrm{~B}_{2} \mathrm{O}_{6}$ and $\mathrm{Mg}_{2} \mathrm{~B}_{2} \mathrm{O}_{5}$ 
ceramics," Journal of the European Ceramic Society, vol. 30, no. 2, pp. 413-418, 2010.

[6] H. Guler, F. Kurtulus, E. Ay, G. Celik, and I. Dogan, " $\mathrm{Mg}_{2} \mathrm{~B}_{2} \mathrm{O}_{5}$ ve $\mathrm{Mg}_{3}\left(\mathrm{BO}_{3}\right)_{2}$ Bilesiklerinin Kati-Hal ve Mikrodalga Yintemle Sentezleri ve Karakterizasyon Aalismalari," in Proceedings of the 4th International Boron Symposium, Eskisehir, Turkey, 2009.

[7] A. F. Qasrawi, T. S. Kayed, A. Mergen, and M. Gürü, "Synthesis and characterization of $\mathrm{Mg}_{2} \mathrm{~B}_{2} \mathrm{O}_{5}$," Material Research Bulletin, vol. 40, pp. 583-589, 2005.

[8] E. M. Elssfah, A. Enousi, J. Zhang, H. S. Song, and C. Tang, "Synthesis of magnesium borate nanorods," Materials Letters, vol. 61, pp. 4358-4361, 2007.

[9] S. Li, X. Fang, J. Leng, H. Shen, Y. Fan, and D. Xu, "A new route for the synthesis of $\mathrm{Mg}_{2} \mathrm{~B}_{2} \mathrm{O}_{5}$ nanorods by mechano-chemical and sintering process," Materials Letters, vol. 64, no. 2, pp. 151$153,2010$.

[10] H. Erdogan, Çözeltide Yanma Yintemiyle Magnezyum Boratlarin Sentezi ve Karakterizasyonu [M.S. thesis], Hacettepe University, Institude of Graduate Studies in Science, Ankara, Turkey, 2008.

[11] E. Ay, Magnezyum Boratlı Bileşiklerin Katı-Hal Kimyasal Yöntemlerle Sentezlenmesi ve Karakterizasyon Çalışmaları [M.S. thesis], Balikesir University, Institude of Graduate Studies in Science, Balikesir, Turkey, 2006.

[12] J. Zhang, Z. Li, and B. Zhang, "Formation and structure of single crystalline magnesium borate $\left(\mathrm{Mg}_{3} \mathrm{~B}_{2} \mathrm{O}_{6}\right)$ nanobelts," Materials Chemistry and Physics, vol. 98, no. 2-3, pp. 195-197, 2006.

[13] Y. Zeng, H. Yang, W. Fu et al., "Synthesis of magnesium borate $\left(\mathrm{Mg}_{2} \mathrm{~B}_{2} \mathrm{O}_{5}\right)$ nanowires, growth mechanism and their lubricating properties," Materials Research Bulletin, vol. 43, no. 8-9, pp. 2239-2247, 2008.

[14] Y. Li, Z. Fan, J. G. Lu, and R. P. H. Chang, "Synthesis of magnesium borate $\left(\mathrm{Mg}_{2} \mathrm{~B}_{2} \mathrm{O}_{5}\right)$ nanowires by chemical vapor deposition method," Chemistry of Materials, vol. 16, no. 13, pp. 2512-2514, 2004.

[15] R. Ma, Y. Bando, and T. Sato, "Nanowires of metal borates," Applied Physics Letters, vol. 81, no. 18, pp. 3467-3469, 2002.

[16] V. L. Stolyarova, S. I. Lopatin, S. M. Shugurov, and A. L. Shilov, "Thermodynamic properties of silicate glasses and melts: VII.1 system $\mathrm{MgO}-\mathrm{B}_{2} \mathrm{O}_{3}-\mathrm{SiO}_{2}$," Russian Journal of General Chemistry, vol. 80, no. 12, pp. 2405-2413, 2010.

[17] E. Moroydor Derun, A. S. Kipcak, S. E. Gurel, and S. Piskin, "Microwave assisted solid-state synthesis of magnesium borate hydrates at 270W," in International Conference on Chemical Engineering (ICCE '12), Paris, France, 2012.

[18] H. S. Fogler, Element of Chemical Reaction Engineering, Prentice-Hall, New Jersey, NJ, USA, 3rd edition, 1999. 

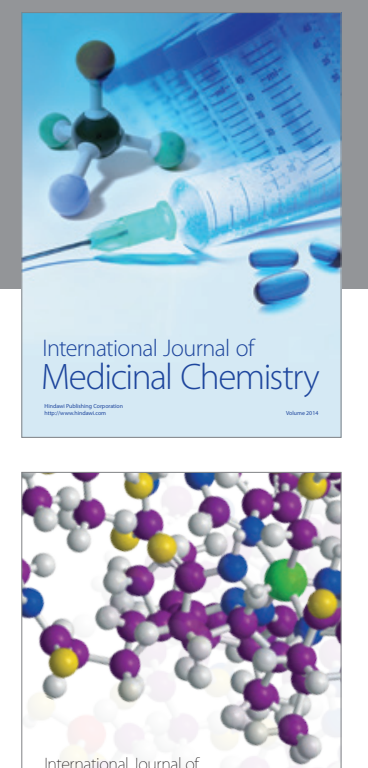

\section{Carbohydrate} Chemistry

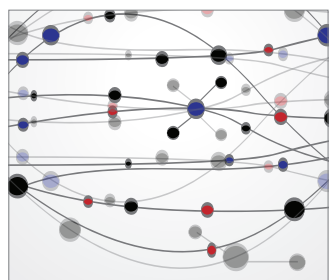

The Scientific World Journal
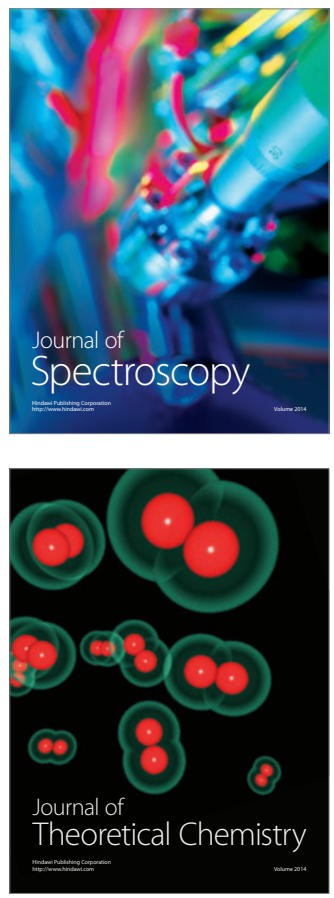
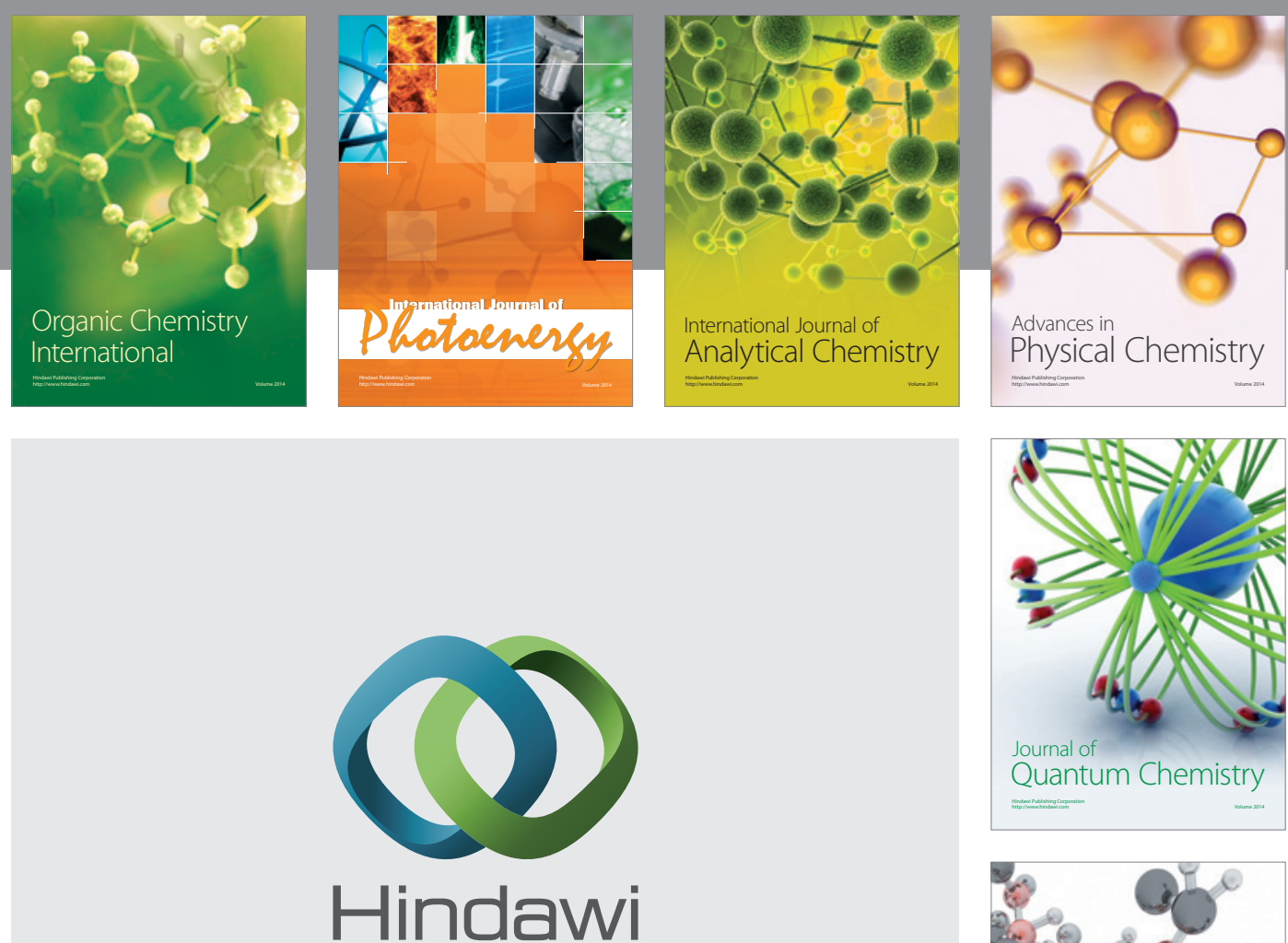

Submit your manuscripts at

http://www.hindawi.com

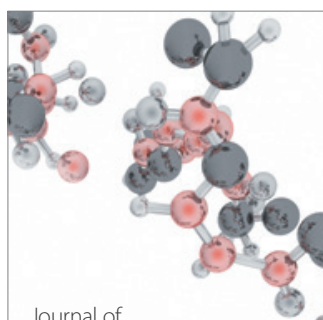

Analytical Methods

in Chemistry

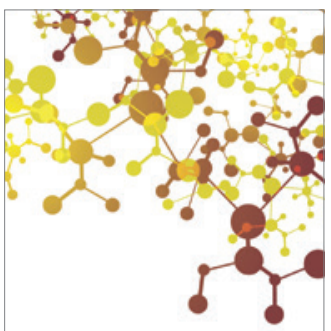

Journal of

Applied Chemistry

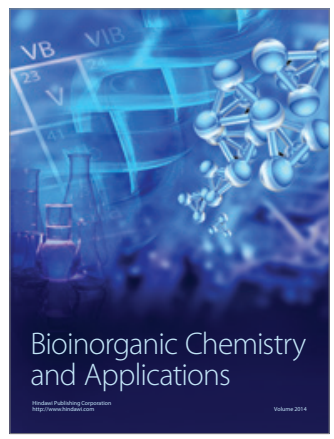

Inorganic Chemistry
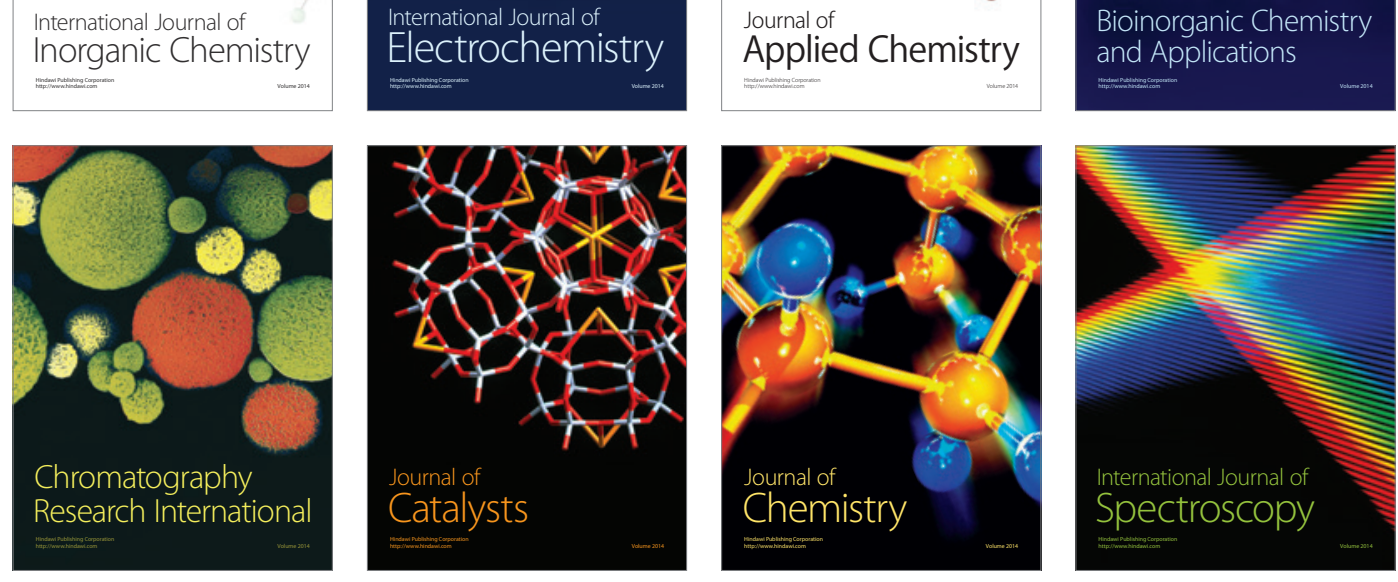